Marquette University

e-Publications@Marquette

Economics Faculty Research and Publications

Economics, Department of

$3-1-2018$

The Effectiveness of Central Bank Forward Guidance Under Inflation and Price-level Targeting

Stephen J. Cole

Marquette University, stephen.cole@marquette.edu

Accepted version. Journal of Macroeconomics, Vol. 55 (March 2018): 146-161. DOI. (C 2018 Elsevier B.V. Used with permission. 


\section{Marquette University}

\section{e-Publications@Marquette}

\section{Economics Faculty Research and Publications/College of Business Administration}

This paper is NOT THE PUBLISHED VERSION; but the author's final, peer-reviewed manuscript. The published version may be accessed by following the link in the citation below.

Journal of Macroeconomics, Vol. 55 (March 2018): 146-161. DOI. This article is (C) Elsevier and permission has been granted for this version to appear in e-Publications@Marquette. Elsevier does not grant permission for this article to be further copied/distributed or hosted elsewhere without the express permission from Elsevier.

\section{Contents}

Abstract .2

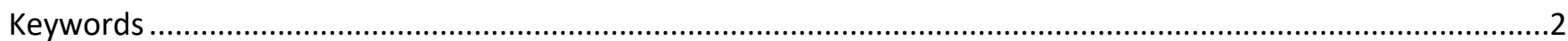

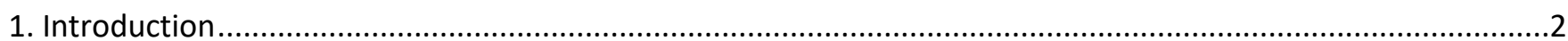

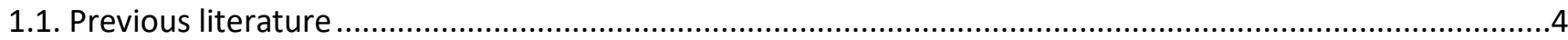

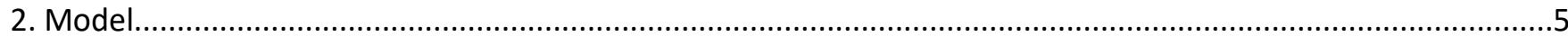

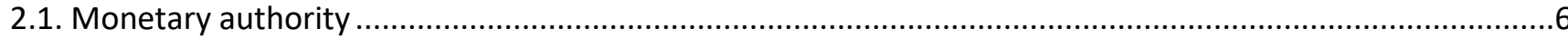

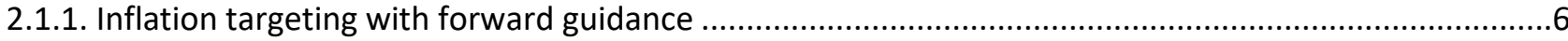

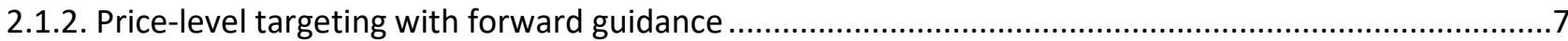

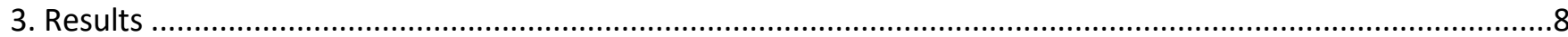

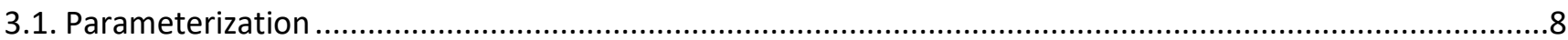

3.2. The effects of forward guidance under inflation and price-level targeting ..............................................9

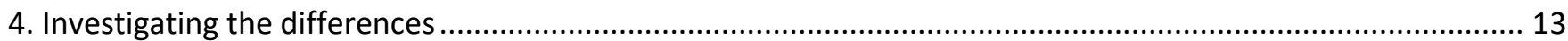

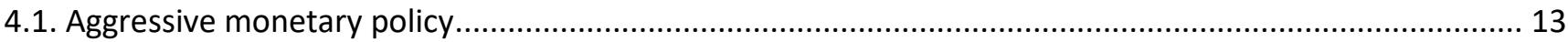

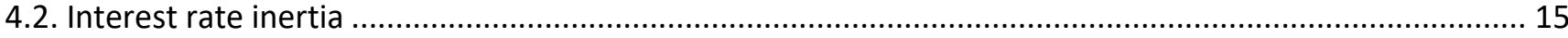

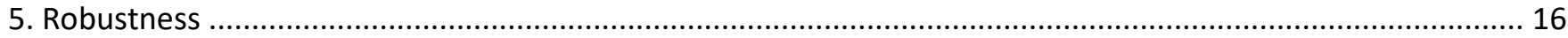

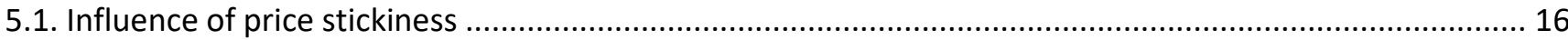

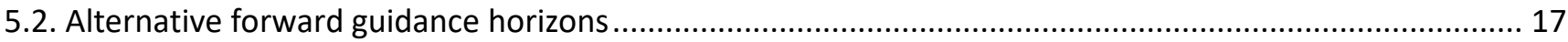

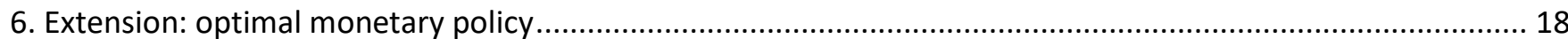




\title{
The Effectiveness of Central Bank Forward Guidance Under Inflation and Price-level Targeting
}

\author{
Stephen J. Cole \\ Department of Economics, Marquette University, Milwaukee, WI
}

\begin{abstract}
This paper examines the effectiveness of central bank forward guidance under inflation and price-level targeting monetary policies. The results show that the beneficial effects of forward guidance increase if a central bank pursues price-level targeting instead of inflation targeting. Output and inflation respond more favorably to forward guidance with price-level targeting than inflation targeting. A monetary policy rule that aggressively reacts to inflation and includes interest rate inertia narrows the performance gap between the two policy regimes. However, forward guidance with price-level targeting is still preferred to forward guidance with inflation targeting after performing multiple robustness checks.
\end{abstract}

\section{Keywords}

Forward guidance, Inflation targeting, Price-level targeting, Monetary policy

\section{Introduction}

The 2007-2009 global financial crisis caused severe adverse effects on economies around the world. Central banks reacted by implementing unconventional monetary policies as their usual policy of lowering overnight interest rates had become exhausted due to the zero lower bound (ZLB). A new tool enacted was forward guidance where the future course of monetary policy is communicated to the public by the central bank. For example, the U.S. Federal Reserve announced guidance on the future path of the short-term interest rate. Another instance regards information about its long-term inflation target. For example, the U.S. Federal Reserve communicated in 2012 that "The Committee judges that inflation at the rate of 2 percent ...is most consistent over the longer run with the Federal Reserve's statutory mandate" (Federal Reserve, 2012). In this case, forward guidance is in terms of the path of the Federal Reserve's long-run inflation target. However, even with these additional stimulative measures, U.S. inflation had missed its Federal Reserve target of $2 \%$ from the period May 2012 to January $2017 .{ }^{1}$ Thus, is there another way to increase the effectiveness of forward guidance?

The debate about whether a central bank should switch from targeting the inflation rate to the price level has been accentuated because of the adverse effects of the Great Recession. ${ }^{2}$ Standard central bank practice and macroeconomic models recommend a monetary policy that targets the inflation rate. Targeting the rate of inflation instead of the price level can achieve lower amounts of fluctuations in output and inflation than pricelevel targeting (see Lebow et al., 1992 and Haldane and Salmon, 1995). However, the period from May 2012 through January 2017 witnessed historic low levels of U.S. inflation as it missed its Federal Reserve target 
throughout this duration. In contrast, targeting the price-level theorizes stimulative effects to the inflation rate. This monetary policy regime predicts a period of above average inflation after a deflationary episode as the central bank must rapidly raise the price level back to its target path. ${ }^{3}$ Thus, a natural question that arises is if price-level targeting can increase the positive effects of forward guidance on the economy.

This paper investigates the effectiveness of forward guidance across two monetary policy regimes: inflation and price-level targeting. A standard New Keynesian model is extended to include a monetary policy rule that takes two forms. The first policy responds to deviations of the inflation rate from its target. The alternative is a monetary authority that changes the interest rate due to deviations of the price level from its target. The targeted price level grows at a rate defined by the central bank's inflation target. Forward guidance is included in the model via the central bank communicating about the future course of its inflation target. Anticipated shocks are added to the inflation target. These shocks represent future deviations in the inflation target known to agents and communicated by the monetary authority today.

The key difference between inflation and price-level targeting monetary policies regards history dependence. Under the former regime, history dependence is inherently absent. For instance, historical inflationary shocks do not play a role in inflation targeting policy. If an adverse shock produced a decline in inflation and the price level, a monetary authority that targets the inflation rate would only be concerned with bringing inflation back to its target level. Since it lets bygones be bygones, the drop in the price level does not concern an inflation targeting central bank. In contrast, a price-level targeting regime is inherently history dependent. It reacts to the low price level caused by the prior adverse shocks by bringing the price level back to its higher target. This action creates a period of above average inflation. ${ }^{4}$

The results show that the beneficial effects of forward guidance increase if a central bank pursues price-level targeting instead of inflation targeting monetary policy. These outcomes are shown during a period of severe economic decline. The monetary authority responds to this recession by implementing forward guidance in the form of a constant level for the future path of its inflation target. ${ }^{5}$ The values of output and inflation are higher under forward guidance with price-level targeting than forward guidance with inflation targeting. The results also favor forward guidance under the former than latter monetary policy when utilizing a loss function based on variances of inflation, output, and the interest rate. The values of this loss function are higher under forward guidance with inflation targeting than forward guidance with price-level targeting.

The reasons for the favorable effects of forward guidance under price-level targeting than inflation targeting are twofold. The first regards the inherent history dependence feature of the former monetary policy regime. A price-level targeting central bank reacts to the drop in inflation and the price level by using policy to rapidly bring the latter macroeconomic variable back to its target. This action results in periods of above average inflation. The second reason concerns how the expectations of agents react to forward guidance statements given by the monetary authority. In response to central bank forward guidance, agents' expectations of output and inflation are more favorable under price-level than inflation targeting. Under the former monetary policy, agents expect higher future inflation as the central bank will target a higher price level than otherwise would exist. The increases in inflation expectations lead to higher levels of output expectations. These combined effects result in larger levels of current output and inflation.

The favorable results under forward guidance with price-level targeting hold across different policy scenarios. The first investigates whether the performance gap between the two policy regimes with forward guidance can be reduced if there is a more aggressive monetary policy. A central bank that responds more to deviations of the inflation rate from its target than it did before can narrow this gap between forward guidance with inflation targeting and forward guidance with price-level targeting. Introducing interest rate inertia also alleviates the disparity. By including a lagged interest rate in both inflation and price-level targeting monetary policy rules, the 
differences are reduced as the first policy regime has a level of history dependence closer to the second policy regime. However, forward guidance still has more favorable outcomes under price-level than inflation targeting.

The model's main results are also robust to different degrees of price stickiness and forward guidance horizons. When lowering the level of price stickiness in the model, the levels of output and inflation are still higher under forward guidance with price-level targeting than forward guidance with inflation targeting. When varying the length of the forward guidance horizon, output and inflation respond to forward guidance more favorably under price-level than inflation targeting.

Overall, the results indicate a primary takeaway: a central bank that pursues price-level targeting instead of inflation targeting can produce more favorable responses of macroeconomic variables to forward guidance. For instance, output and inflation are higher under forward guidance with price-level targeting than inflation targeting. These results are also confirmed under alternative scenarios.

\subsection{Previous literature}

The current paper contributes to previous research on the effectiveness of central bank forward guidance. Eggertsson and Woodford (2003) explain how central bank communication about the future course of policy (e.g. the path of interest rates) is pertinent for successful monetary policy. Swanson and Williams (2014) empirically show that medium- and longer-term interest rates are influenced by forward guidance communication. De Graeve et al. (2014) find that the effectiveness of forward guidance depends on the rationale for implementing this policy. For instance, if the central bank communicates that the reason for lower than normal interest rates in the future is a forecasted downturn in the economy, the effectiveness of forward guidance will increase. In addition, Carlstrom et al. (2012) and Del Negro et al. (2012) show that standard macroeconomic models predict extreme responses of the variables to forward guidance. McKay et al. (2015)explain that these predictions vary depending on the assumption of complete markets. Cole (2015) and Cole (2016) state that the unusually large responses and the effectiveness of this unconventional monetary policy tool may be due to the manner in which expectations are modeled. Furthermore, the current paper augments these studies by examining the effectiveness of forward guidance when the central bank implements price-level targeting.

Prior studies have shown the positive benefits of a price-level targeting central bank. Woodford (2003) describes that a history dependent central bank can improve the power of monetary policy when agents are forward looking. Svensson (1999) shows that this monetary policy regime acting under discretion can reduce fluctuations in the inflation rate relative to an inflation targeting central bank. Ball et al. (2005) describe that price-level targeting is the optimal policy prescription regardless of the type of shock that affects the economy. Under a central bank acting with discretion, Vestin (2006) also finds that price-level targeting is preferable to an inflation targeting regime because the former monetary policy regime results in a better tradeoff between inflation and output gap variability. Giannoni (2014) explains that price-level targeting outperforms inflation when judging by welfare. Evans (2012); Billi (2008); Wolman (2005), and Eggertsson and Woodford (2003)argue that a price-level targeting monetary policy can alleviate adverse effects of an economy at the ZLB. If there is an adverse shock that drops the price level, Gaspar et al. (2007) describe that agents will forecast a policy that raises the price level in the future. This expected increase raises inflation expectations and lowers real interest rates. Consequently, the decrease in the real interest rate stimulates the economy. Similarly, Cover and Pecorino (2005) show that a negative inflation shock causes an increase in expected inflation under price-level targeting, which lowers the real interest rate and increases output. Billi (2015b) shows that price-level targeting is more effective than nominal GDP level targeting when the future state of the economy is uncertain. Shukayev and Ueberfeldt (2010) explore the type of price index to pursue for a price-level targeting central bank. In addition, Dowd (2007) describes that the Bank of England's inflation targeting policy resembles a price-level targeting strategy as it is dependent on previous period's inflation. ${ }^{6}$ 
Price-level targeting has been studied when relaxing the rational expectations

hypothesis. Williams (2010) investigates this monetary policy under adaptive learning and at the

ZLB. Honkapohja and Mitra (2015b) examine the performance of inflation, price level, and nominal GDP targeting policies under a New Keynesian model with adaptive learning. ${ }^{7}$ They introduce forward guidance on the targeted price level or nominal GDP. The addition of forward guidance to either price level or nominal GDP targeting can help the economy avoid a liquidity trap.

The contribution of the current paper to the literature is that it examines how the effectiveness of central bank forward guidance depends on the monetary policy regime. ${ }^{8}$ The preceeding paragraphs explain that a majority of the prior literature has explored forward guidance and price-level targeting separately. However, some previous studies have combined forward guidance and price-level targeting. Levin et al. (2010) model forward guidance at the ZLB under optimal policy. One of their paper's extensions compares a price-level targeting regime to the optimal commitment scenario. Honkapohja and Mitra (2015a) and Honkapohja and Mitra (2015b) examine inflation, price-level, and nominal gross domestic product (NGDP) targeting regimes. Forward guidance is included in price-level targeting or NGDP, but not in an inflation targeting central bank. Thus, to the best of my knowledge, none of the prior literature has explicitly examined how the effects of forward guidance vary across inflation and price-level targeting monetary policy rules. In addition, the main results of the current paper demonstrate that the effectiveness of forward guidance increases when a central bank pursues price-level targeting instead of inflation targeting. The main mechanism behind this result is the expectations channel. The literature has shown that a price-level targeting monetary policy favorably affects expectations of agents [see Amano et al. (2011) and Cover and Pecorino (2005)]. The current paper demonstrates that the effectiveness of forward guidance is boosted by a price-level targeting regime relative to an inflation targeting strategy since forward guidance operates through the expectations channel.

The rest of the paper is organized as follows. Section two presents the New Keynesian model with forward guidance under both inflation and price-level targeting. Section three shows the results of the model with forward guidance under both types of monetary policy regimes. Section four investigates the disparity between the responses of the macroeconomic variables to forward guidance with inflation targeting and forward guidance with price-level targeting. Specifically, it examines the model's outcomes under an aggressive monetary policy and with or without interest rate inertia. Section five contains robustness exercises in which the degree of price stickiness and the length of the forward guidance horizon vary. Section six compares forward guidance under inflation and price-level targeting regimes to optimal monetary policy. Section seven concludes.

\section{Model}

The economy's aggregate dynamics are described by the benchmark New Keynesian model analyzed in Woodford (2003) and Preston (2005). The model is derived from microfoundations and contains three sectors: households, firms, and a monetary authority. The log-linearized equations modeling the first two are given by

(1) $x_{t}=E_{t} x_{t+1}-\sigma\left(i_{t}-E_{t} \pi_{t+1}\right)+r_{t}^{n}$

(2) $\pi_{t}=\beta E_{t} \pi_{t+1}+\kappa x_{t}+\mu_{t}$

Eq. (1) represents aggregate demand in the economy. $x_{t}$ denotes the output gap, which is output in deviation from the efficient level of output (see Galí, 2008). The output gap is a function of expected one-period ahead output gap $\left(E_{t} x_{t+1}\right)$, the nominal interest rate $\left(i_{t}\right)$, expected one-period ahead inflation $\left(E_{t} \pi_{t+1}\right)$, and the natural real rate interest shock $\left(r_{t}^{n}\right) . \sigma>0$ measures the intertemporal elasticity of substitution of consumption across periods. Bis the household's discount rate and is assumed bound between 0 and 1 (i.e. $0 \leq 6 \leq 1$ ). In addition, firms operate in a monopolistically competitive environment in which they use labor from households to produce their goods. Following Calvo (1983), a fraction $0<1-\alpha<1$ of producers are able to reoptimize each 
period with respect to their price. The remaining $\alpha$ of firms set prices according to the previous period's price level. The resulting equation representing the supply side of the economy and the New Keynesian Phillips curve is given by (2). It relates inflation to expected one-period ahead inflation, output gap, and a cost-push shock $\left(\mu_{t}\right)$.

The parameter $\kappa \equiv \frac{(1-\alpha)}{\alpha} \frac{(1-\alpha \beta)}{(1+\omega \theta)}\left(\omega+\sigma^{-1}\right)>0$ with $\vartheta>1$ representing the elasticity of substitution across differentiated goods. $\omega$ is the elasticity of a firm's real marginal cost with respect to increasing its output. In addition, the price level is defined by

(3) $p_{t}=\pi_{t}+p_{t-1}$

The structural disturbances are assumed to follow AR(1) processes given by

(4) $r_{t}^{n}=\rho_{n} r_{t-1}^{n}+\varepsilon_{t}^{n}$

(5) $\mu_{t}=\rho_{\mu} \mu_{t-1}+\varepsilon_{t}^{\mu}$

$\varepsilon_{t}^{n}$ and $\varepsilon_{t}^{\mu}$ are assumed to be i.i.d. and drawn from a Normal distribution, that

is, $\varepsilon_{t}^{n} \stackrel{\text { iid }}{\sim} N\left(0, \sigma_{n}^{2}\right)$ and $\varepsilon_{t}^{\mu} \stackrel{\text { iid }}{\sim} N\left(0, \sigma_{\mu}^{2}\right)$.

\subsection{Monetary authority}

The model is closed by describing the central bank. The monetary authority is assumed to follow a policy rule by either targeting the inflation rate or the price level. The central bank issues forward guidance on the inflation target. ${ }^{9}$ This act is akin to the Federal Reserve communicating to the public that its long-run inflation target is 2\%. For instance, the Federal Reserve declared in January 2012 that "The Committee judges that inflation at the rate of 2 percent ...is most consistent over the longer run with the Federal Reserve's statutory mandate" (Federal Reserve, 2012). The next two subsections describe central bank monetary policy rules under forward guidance with inflation targeting and forward guidance with price-level targeting.

\subsubsection{Inflation targeting with forward guidance}

When targeting the inflation rate of the economy, the central bank follows a rule similar to Taylor (1993). It is assumed to adjust the nominal interest rate to changes in itself, output gap, inflation from its target, and an unanticipated monetary policy shock. Accordingly, the monetary policy rule is given by

(6) $i_{t}=\rho i_{t-1}+(1-\rho)\left[\chi_{\pi}\left(\pi_{t}-\pi_{t}^{*}\right)+\chi_{x} x_{t}\right]+\varepsilon_{t}^{M P}$

where $\varepsilon_{t}^{M P}$ is i.i.d. and drawn from a Normal distribution, that is, $\varepsilon_{t}^{M P} \stackrel{i i d}{\sim} N\left(0, \sigma_{M P}^{2}\right)$.

Following Del Negro et al. (2014); Milani and Treadwell (2012), and Milani (2009), the inflation target $\pi_{t}^{*}$ is assumed to be time varying and is given by

(7) $\pi_{t}^{*}=\rho_{\pi} \pi_{t-1}^{*}+\varepsilon_{t}^{\pi^{*}}$

In addition, the monetary authority communicates to the public guidance on the future course of the inflation target $\pi_{t}^{*}$. To model this central bank forward guidance, Eq. (7) is augmented in the following way:

(8)

$\pi_{t}^{*}=\rho_{\pi^{*}} \pi_{t-1}^{*}+\varepsilon_{t}^{\pi^{*}}+\sum_{l=1}^{L} \varepsilon_{t, t-l}^{F G}$ 
The central bank adjusts its inflation target to changes in the previous period's target, an unanticipated inflation target shock, and forward guidance shocks. ${ }^{10}$ I assume that $\varepsilon_{t}^{\pi^{*}} \stackrel{i i d}{\sim} N\left(0, \sigma_{\pi^{*}}^{2}\right)$. Forward guidance is included in the model via anticipated or forward guidance shocks contained in the last term in Eq. (8). Each forward guidance $\operatorname{shock}\left(\varepsilon_{t, t-l}^{F G}\right)$ is i.i.d. and represents communication by the central bank in period $t-l$ that the inflation target will change / periods later (i.e. in period $t$ ). ${ }^{11}$ If the monetary authority has been communicating forward guidance for $1,2, \cdots, L$ periods ahead, Eq. (8) would contain $L$ forward guidance shocks that affect the inflation target. Therefore, the duration of the forward guidance horizon is defined by $L$.

Following Del Negro et al. (2012) and Laséen and Svensson (2011), the forward guidance shocks are expressed in recursive form by adding the following equations:

\begin{tabular}{|c|c|c|}
\hline (9) $v_{1, t}$ & $=$ & $v_{2, t-1}+\varepsilon_{1, t}^{F G}$ \\
\hline 10) $v_{2, t}$ & $=$ & $v_{3, t-1}+\varepsilon_{2, t}^{F G}$ \\
\hline 11) $\begin{array}{c}\vdots \\
v_{L, t}\end{array}$ & $=$ & $\varepsilon_{L, t}^{F G}$ \\
\hline
\end{tabular}

The vector $v_{t}=\left[v_{1, t}, v_{2, t}, \cdots, v_{L, t}\right]{ }^{\prime}$ contains all central bank promises known to agents in period $t$ that the inflation target will change $1,2, \cdots, L$ periods later. For instance, $v_{1, t}$ defines all forward guidance information that agents know in period $t$ such that the inflation target will change one period later. It contains central bank communication given to agents in period $t-1$ that influences the inflation target 2 periods later $\left(v_{2, t-1}\right)$ and current period forward guidance affecting the inflation target one period later $\left(\varepsilon_{1, t}^{F G}\right)$. Since $L$ is the maximum amount of periods ahead that the central bank issues forward guidance, $v_{L, t}$ only contains current period forward guidance that affects the inflation target $L$ periods later. In addition, one can use Eqs. (9) - (11) to show that $v_{1, t-1}=\sum_{l=1}^{L} \varepsilon_{t, t-l}^{F G}$, which is the last term in Eq. (8). It should also be noted that modeling forward guidance as in Eqs. (8) - (11) provides a tractable way to model a constant inflation target path. The forward guidance shocks in Eqs. (9) - (11) can be chosen so that the inflation target is constant across the forward guidance horizon. This path is similar to the Federal Reserve announcing a long-run inflation target of $2 \%$. This exercise will be described in Section 3.2.

Forward guidance has previously been modeled in the literature via the same anticipated shocks described in this section. However, prior research has focused on forward guidance on the interest rate. Specifically, the anticipated shocks are included in the monetary policy rule and the forward guidance shocks are chosen such that the interest rate $i_{t}$ is constant Lperiods into the future (see Laséen and Svensson (2011); Del Negro et al. (2012), and Cole (2015) and Cole (2016)). The current paper differs from prior research in two ways. First, the anticipated or forward guidance shocks are included in the inflation target as shown in Eq. (8). As will be described in Section 3.2, the forward guidance shocks will also be chosen such that the inflation target (and not the interest rate) is constant $L$ periods into the future.

\subsubsection{Price-level targeting with forward guidance}

When targeting the price level in the economy, the central bank adjusts the short-term nominal interest rate to changes in itself, output gap, price level from its target, and an unanticipated monetary policy shock.

Following Honkapohja and Mitra (2015a); (2015b), and Giannoni (2014), the monetary policy rule under a pricelevel targeting regime is given by

(12) $i_{t}=\rho i_{t-1}+(1-\rho)\left[\chi_{p}\left(p_{t}-\bar{p}_{t}\right)+\chi_{x} x_{t}\right]+\varepsilon_{t}^{M P}$

where $\varepsilon_{t}^{M P}$ is defined as in Eq. (6). Following Woodford (2003, chap. 2), a monetary policy regime under Eq. (12) is called "Wicksellian." In addition, the difference between inflation and price-level targeting rules 
is that the central bank under the latter policy responds to changes in the price level from a deterministic trend $\bar{p}_{t}$ that satisfies

(13) $\bar{p}_{t}=\bar{p}_{t-1}+\pi^{*}$

Central bank forward guidance is added to the price-level targeting regime by replacing $\pi^{*}$ in Eq. (13) with the time-varying inflation target with forward guidance as defined in Eq. (8). The targeted price level becomes

(14) $\bar{p}_{t}=\bar{p}_{t-1}+\pi_{t}^{*}$

In other words, the central bank is giving guidance on the future course of the long-run inflation target. ${ }^{12}$ Since this is the same forward guidance on the inflation target as in Section 2.1.1, I can compare the effects of forward guidance under both inflation and price-level targeting regimes. To re-emphasize the point made in the previous subsection, forward guidance also will be implemented such that the time-varying inflation target will be constant.

The monetary policy regimes in Eqs. (6) and (12) share both similarities and differences. An important similarity is that both inflation and price-level targeting monetary policy rules respond to the lagged interest rate, which implies at least some common degree of history dependence for the two policies. However, the key difference between inflation and price-level targeting regimes is that the latter includes additional history dependence than that produced with only interest rate inertia. ${ }^{13}$ Under a price-level targeting regime, Eq. (12)shows that the interest rate is adjusted as the price level changes. By Eq. (3), the price level depends on past rates of inflation. Thus, a central bank that targets the price level inherently considers inflationary shocks that occurred in the past when setting monetary policy. For example, it will react to previous declines in inflation and price level by using its policy tool to spring the price level back to its higher target. This policy action creates a period of above average inflation. This result is an important feature of the price-level targeting regime and will be discussed further in Section 3.2.

To summarize, the model with forward guidance and inflation targeting is given by aggregate demand, New Keynesian Phillips Curve, price level, AR(1) processes for the structural disturbances, monetary policy rule with inflation targeting, time-varying inflation target, and all central bank promises regarding changing the inflation target, that is, Eqs. (1)-(6) and (8)-(11). When the monetary authority implements forward guidance and targets the price level, Eq. (6) is replaced by Eqs. (12) and (14).

\section{Results}

\subsection{Parameterization}

The values of the model's structural parameters are displayed in Table 1 and are based on previous literature. $\beta=0.99$ is a standard value used in prior studies. The intertemporal elasticity of substitution of consumption across periods, $\sigma$, is set to 0.15 . This closely follows Fuhrer (2000). The degree of price stickiness in the model is assumed to be high at 0.95 , which is slightly higher than found in Milani and Treadwell (2012). The value of $\kappa$ is set to 0.001 . This number corresponds to the values of $\vartheta$ and $\omega$ used in Milani and Treadwell (2012). As a robustness check in Section 5.1, the model's main results will be examined under a lower degree of price stickiness, and thus, a different value of $\kappa$. There also exists a high degree of persistence in $r_{t}^{n}$ as $\rho_{n}=$ 0.95 which agrees closely with Kuester, (Kuester et al., 2007). The value of $\rho_{\mu}$ is set to equal 0.5 , which roughly follows the rational expectations model of Milani (2009). I also assume that the white noise shocks are not highly dispersed and there is no covariance between them.

\section{Table 1. Parameter values.}

\section{Description}

$\sigma \quad$ IES

B Discount Factor
Value

0.15

0.99 


$\begin{array}{lll} & \text { Description } & \text { Value } \\ \boldsymbol{\kappa} & \text { Function of Price Stickiness } & 0.001 \\ \boldsymbol{\alpha} & \text { Price Stickiness } & 0.95 \\ \boldsymbol{\chi}_{\boldsymbol{\pi}} & \text { Feedback Inflation } & 1.4 \\ \boldsymbol{\chi}_{\boldsymbol{x}} & \text { Feedback Output Gap } & 0.1 \\ \boldsymbol{\chi}_{\boldsymbol{p}} & \text { Feedback Price } & 0.25 \\ \boldsymbol{\lambda} & \text { Loss Function } & 0.5 \\ \boldsymbol{v} & \text { Loss Function } & 0.1 \\ \boldsymbol{\rho}_{\boldsymbol{n}} & \text { Autoregressive Demand } & 0.95 \\ \boldsymbol{\rho}_{\boldsymbol{\mu}} & \text { Autoregressive Cost-Push } & 0.5 \\ \rho \pi^{*} & \text { Autoregressive Inflation Target } & 0.99 \\ \boldsymbol{\rho} & \text { Interest Rate Inertia } & 0.75 \\ \boldsymbol{L} & \text { FG Horizon } & 12\end{array}$

Note: The standard deviations of the structural shocks are set to 0.001. FG means forward guidance.

The values of the monetary policy parameters closely follow prior studies. Under an inflation targeting regime, the parameter controlling the response of the interest rate to deviations of inflation from its target is set equal to 1.4. This number roughly follows the rational expectations model found in Milani (2007). Under a central bank targeting the price level, the parameter $\chi_{p}$ governs the response of the interest rate to deviations of the price level from its target. $\chi_{p}$ is set to 0.25 which is taken from Honkapohja and Mitra (2015a); 2015b), and Williams (2010). The central bank also adjusts the interest rate positively to the output gap as $\chi_{x}=$ 0.1 , which follows closely (Cole, 2015). There exists a high degree of inertia in the time-varying inflation target as $\rho_{\pi^{*}}$ is set equal to 0.99. This value follows from Milani (2009)and Del Negro et al. (2014). A high level of interest rate inertia also is present as $\rho=0.75$. In addition, the duration of the central bank's forward guidance horizon $L$ is chosen to be 12 . This value is somewhat arbitrary. Therefore, the model's results will be examined in Section 5.2 under shorter and longer forward guidance horizons as a robustness check.

\subsection{The effects of forward guidance under inflation and price-level targeting}

Forward guidance and price-level targeting have received notable consideration since the 2007-2009 financial crisis. Central bank forward guidance was implemented in response to the global financial recession. Evans (2012) also argues that price-level targeting can be justified when the economy is dealing with the effects of an economic recession as the central bank would be missing both components of its dual mandate, that is, high unemployment and low inflation. For instance, price-level targeting can bring a period of above-average inflation to help stimulate the economy. With that event in mind, this section examines the effects of forward guidance under inflation and price-level targeting regimes while the economy is experiencing a recession. This exercise is summarized next and closely follows Cole (2016); 2015), and Del Negro et al. (2012). ${ }^{14}$

A nontechnical description of the exercise is given first before detailing the actual procedure. The economy is assumed to start during a period of "normal" times. A recession then occurs that severely lowers demand, and consequently, inflation. The central bank responds via its unconventional monetary policy tool of forward guidance. Specifically, it announces to the public its long-run target of inflation that will be present in the economy for today and $L$ periods into the future. ${ }^{15}$ The results are then compared across forward guidance with price-level targeting and forward guidance with inflation targeting.

This exercise is implemented in the following manner. The model is simulated until period $T+1$ upon which a large negative demand shock $\left(r_{t}^{n}\right)$ occurs and causes a recession. Negative demand shocks also occur in the following five time periods. ${ }^{16}$ The central bank responds by issuing forward guidance such that the long-run inflation target $\pi_{t}^{*}=\bar{\pi}^{*}$ for today and $L$ periods into the future. This corresponds to an unanticipated change in the current period of $\pi_{t}^{*}$ and anticipated changes of $\pi_{t}^{*}$ for $L$ periods into the future. Specifically, the central bank 
chooses the unanticipated inflation target shock $\left(\varepsilon_{t}^{\pi^{*}}\right)$ and the anticipated forward guidance shocks $\left(\varepsilon_{1, t}^{F G}, \varepsilon_{2, t}^{F G}, \cdots, \varepsilon_{L, t}^{F G}\right)$ such that $\pi_{t}^{*}=\bar{\pi}^{*}$ for the current period and $L$ periods into the future. The macroeconomic results are then compared across inflation and price-level targeting regimes with forward guidance. ${ }^{17}$ Furthermore, by following Honkapohja and Mitra (2015b), the value of $\bar{\pi}^{*}$ is chosen to be 1.005 .

Figs. 1 and 2 and Table 2 show the macroeconomic effects of this forward guidance across the two monetary policy regimes. The panels in Fig. 1 show the value of the macroeconomic variable without forward guidance minus the value with forward guidance. For example, a negative value indicates the variable's value with forward guidance is higher than without forward guidance. The first and second columns denote the results under inflation and price-level targeting, respectively. The top, middle, and bottom panels of Fig. 2 display the difference in the values of the macroeconomic variables between forward guidance with inflation targeting and forward guidance with price-level targeting. For instance, a negative number implies the value of the variable is greater under the latter than former monetary policy. In addition, the top panel of Table 2 under "Benchmark" shows the values of the loss function which is given by

(15) $\mathcal{L}=\operatorname{VAR}\left(\pi_{t}-\pi_{t}^{*}\right)+\lambda V A R\left(x_{t}\right)+v V A R\left(i_{t}\right)$

The second column indicates the value of (15) under forward guidance and inflation targeting, while the third column denotes the value under forward guidance and price-level targeting. Eq. (15) follows from Williams (2010). ${ }^{18}$ I assume $\lambda=0.5$ and $v=0.1$ which is taken from Williams (2010).
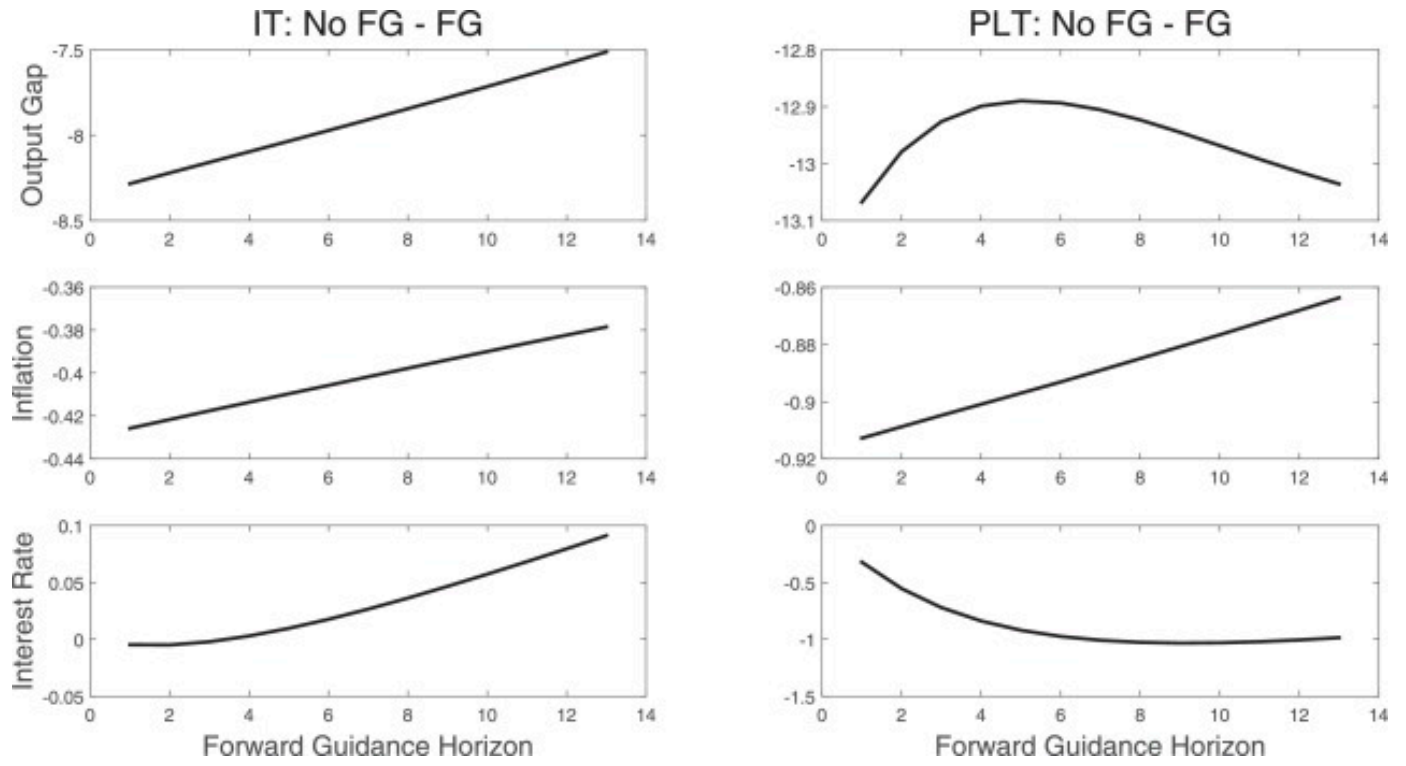

Fig. 1. Macroeconomic effects of forward guidance under inflation and price-level targeting. Note: The graphs show the difference in the macroeconomic variables between no forward guidance and forward guidance. A positive value indicates the value without forward guidance is higher than with forward guidance. A negative value indicates the variable's value with forward guidance is higher than without forward guidance. The first column represents the model under inflation targeting. The second column denotes the model under price-level targeting. IT, PLT, and FG mean inflation targeting, pricelevel targeting, and forward guidance, respectively. 

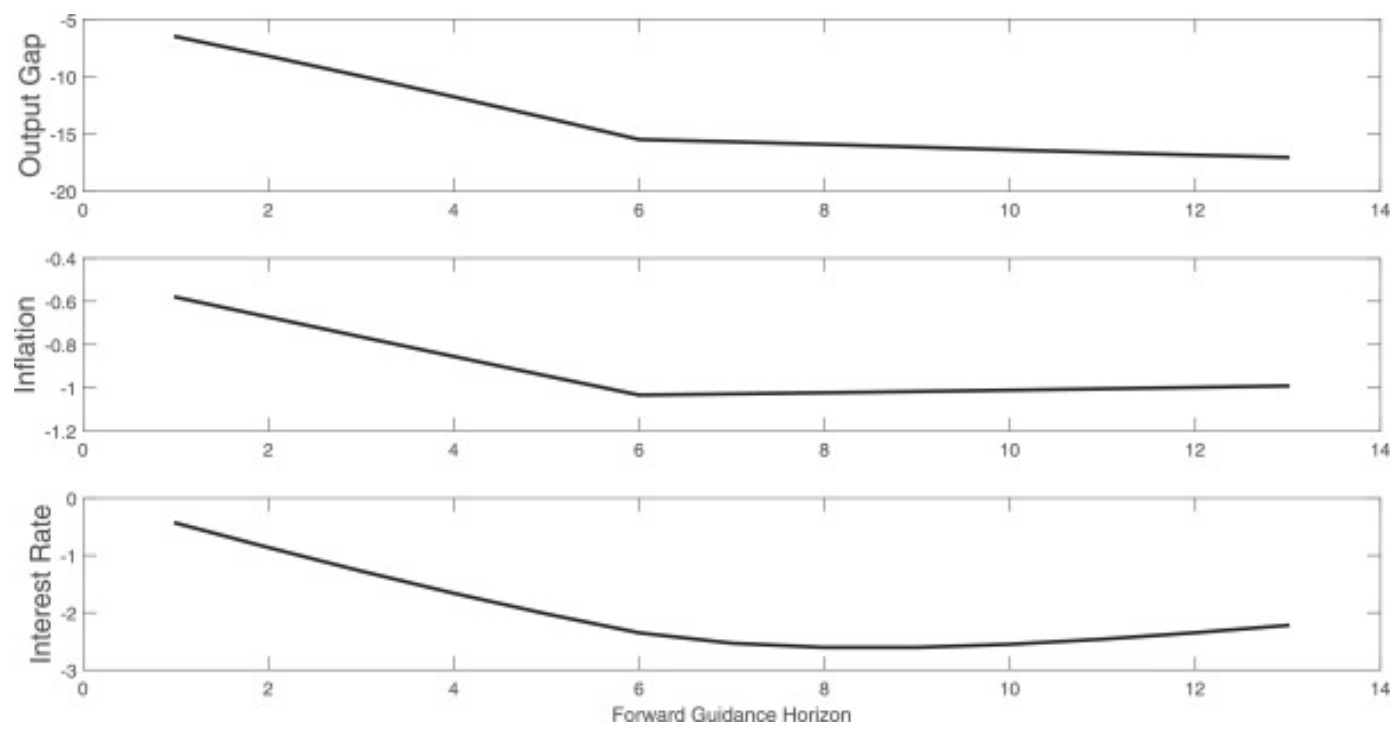

Fig. 2. Difference in output gap, inflation, and interest rate between inflation and price-level targeting. Note: The graphs show the difference in the macroeconomic variables between forward guidance with inflation targeting and forward guidance with price-level targeting. A positive value indicates the value under inflation targeting is higher than under pricelevel targeting. A negative value indicates the variable's value under price-level targeting is higher than under inflation targeting.

Table 2. Loss function values.

Benchmark

Aggressive Inflation Targeting Policy

$\left(\chi_{\pi}=2.5\right)$

Aggressive Price-Level Targeting Policy

$\left(\chi_{p}=1\right)$

No Interest Rate Inertia

$(\rho=0)$

Low Price Stickiness

$(\alpha=0.1)$

Short FG Horizon

$(L=6)$

Long FG Horizon

( $L=18)$

Note: The loss function is found in Eq. (15). FG means forward guidance.
Inflation targeting

166.13

153.17

166.13

178.01

264.23

290.09

127.48
Price-level targeting

117.90

117.90

80.08

119.04

149.91

210.80

106.85

Fig. 1 shows how the effects of forward guidance depend on the monetary policy regime. Under both central bank policies, forward guidance has a more beneficial impact on the macroeconomic variables than without forward guidance. The values of the output gap and inflation are larger with forward guidance than without it. However, the positive impact of forward guidance is greater under price-level than inflation targeting. Thus, the results show that the beneficial effects of forward guidance increase if a central bank pursues price-level targeting instead of inflation targeting monetary policy. ${ }^{19}$

Similar results are also found when directly comparing the values of the macroeconomic variables with forward guidance across both inflation and price-level targeting regimes. Fig. 2 displays the differences between forward guidance under inflation targeting and forward guidance under price-level targeting. The paths of output and inflation under forward guidance with price-level targeting are higher than under forward guidance with inflation targeting. This result agrees with Billi (2008) who found that price-level targeting helps to alleviate the 
probability that an economy will move into a deflationary or recession period. ${ }^{20}$ The top panel in Table 2 under "Benchmark" also describes a similar situation. The loss function's value is lower under forward guidance with price-level targeting than forward guidance with inflation targeting. Under forward guidance with inflation targeting, the value of the loss function is 166.13 while its counterpart is $117.90 .^{21}$

What accounts for the more favorable responses under forward guidance with price-level targeting than forward guidance with inflation targeting? The first reason regards the history dependence feature of the former monetary policy regime. A price-level targeting central bank takes into account the prior declines in the inflation rate and price level due to the recession. It will target a higher price level which leads to subsequent above average inflation. The second reason concerns how agents' forecasts react to the forward guidance statements given by the monetary authority. When the central bank announces that it will pursue a long-term inflation target that is above the current inflation rate, agents will expect a price-level targeting regime to target higher price levels in the future. This generates higher levels of expected inflation and expected output gap under price-level targeting than inflation targeting. Fig. 3 displays this reasoning. The lines in Fig. 3 display the difference in the value of the variable between forward guidance with inflation targeting and forward guidance with price-level targeting. Across the forward guidance horizon, the expectations of the output gap and inflation are higher under price-level targeting than inflation targeting. The higher levels of expected output gap and inflation lead to greater current output gap and inflation under forward guidance with price-level targeting than forward guidance with inflation targeting. In addition, the more favorable responses of expectations under price-level than inflation targeting confirm the statement of Billi $(2008$, pg. 3): "... the policymaker can shape private-sector expectations more effectively under price-level targeting than inflation targeting." Cover and Pecorino (2005) also confirm that price-level targeting has a beneficial effect on influencing expectations. The results in the current paper, however, demonstrate a new contribution. Since a price-level targeting policy is effective at influencing expectations and forward guidance operates through the expectations channel, the effectiveness of forward guidance is boosted under a price-level targeting monetary policy regime relative to an inflation targeting policy.
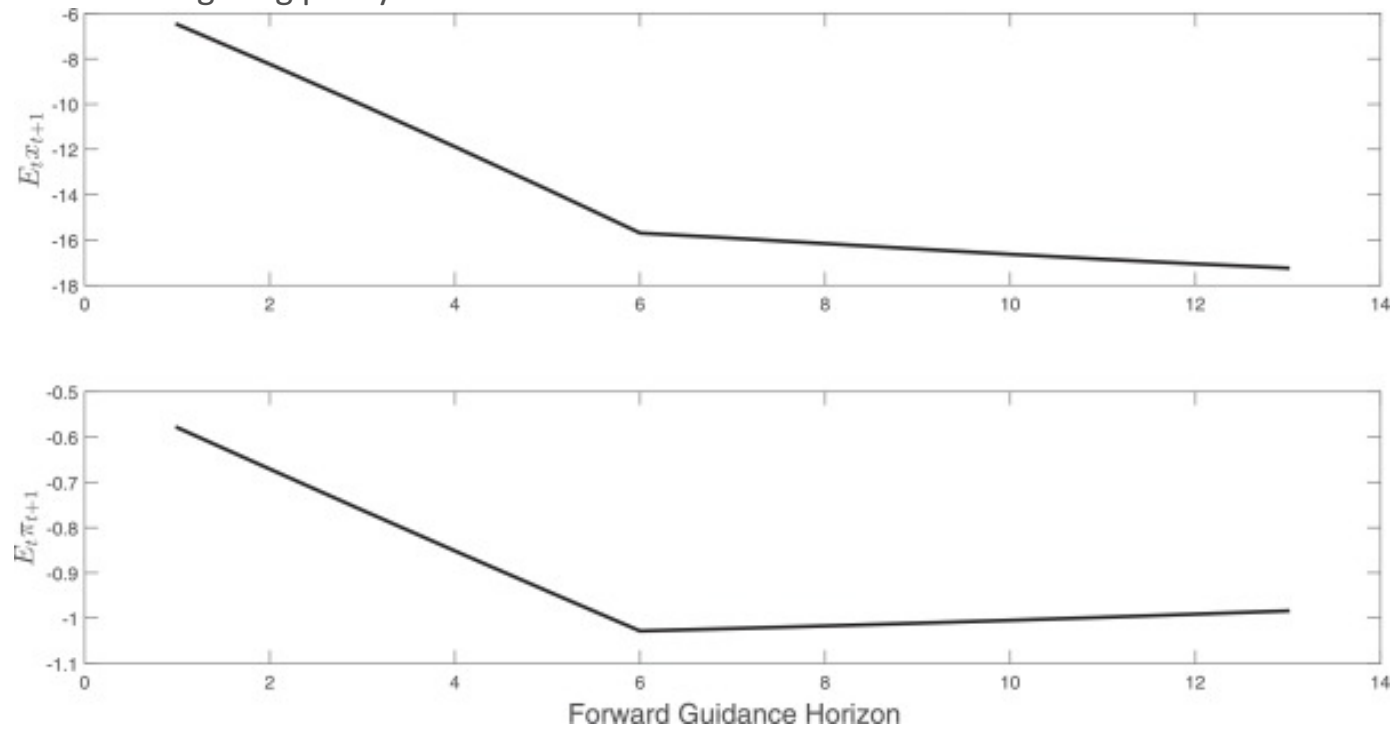

Fig. 3. Difference in the expectations of output gap and inflation between inflation and price-level targeting. Note: The graphs show the difference in expectations between forward guidance with inflation targeting and forward guidance with price-level targeting. A positive value indicates the value under inflation targeting is higher than under price-level targeting. A negative value indicates the variable's value under price-level targeting is higher than under inflation targeting.

It is also helpful to understand the reaction of the interest rate to forward guidance under both monetary policy regimes. Fig. 4 shows the actual responses of the interest rate to forward guidance under both price-level targeting (dashed line) and inflation targeting (solid line). Under both regimes, the forward guidance shocks deliver lower interest rates as both lines contain only negative values throughout the forward guidance horizon. 
A notable feature of Fig. 4 is the lower interest rate under inflation targeting relative to price-level targeting. The reason is that output and inflation are lower under the former than latter monetary policy regime as displayed in Fig. 2. Eqs. (6) and (12) indicate that smaller levels of output and inflation imply lower interest rates under inflation targeting relative to price-level targeting. Moreover, price-level targeting is still more beneficial to the economy as seen in Figs. 1 and 2. The reason is that forward guidance under price-level targeting more positively affects agents' expectations as displayed in Fig. 3.

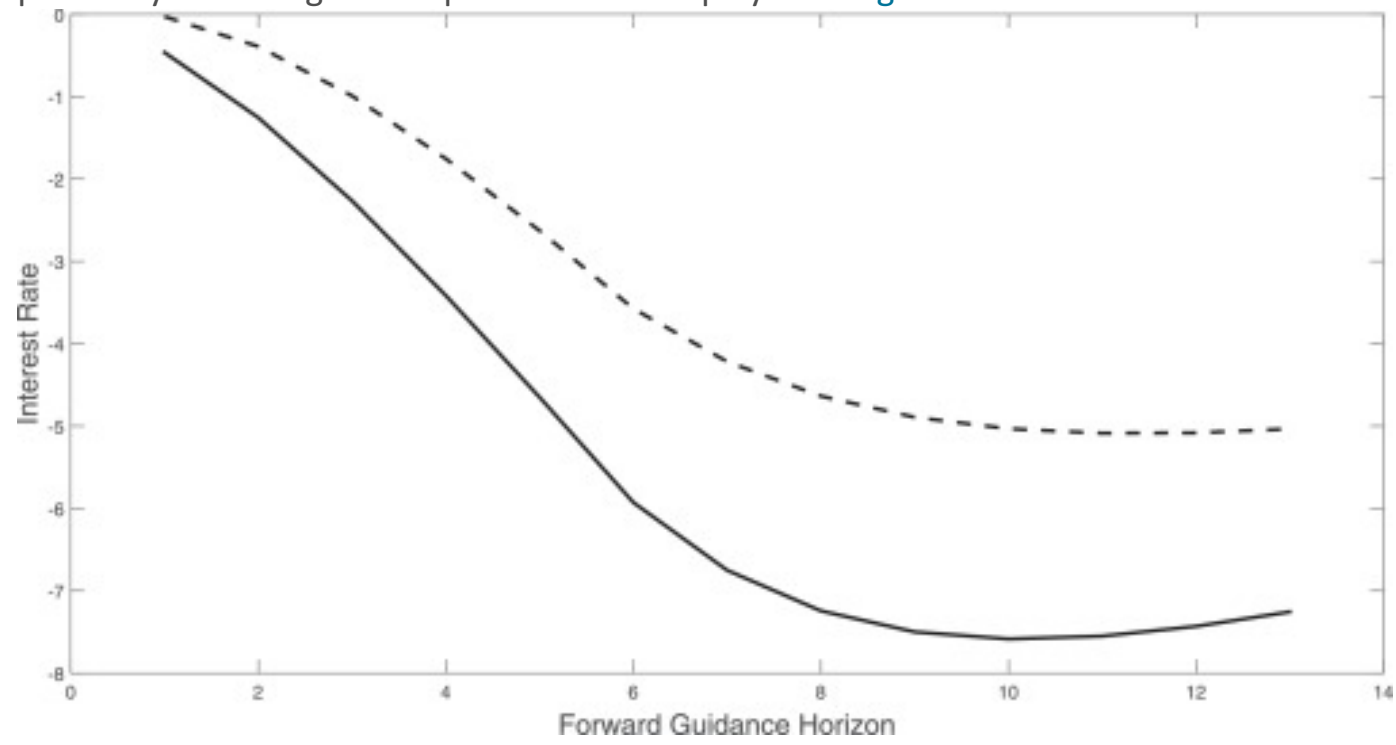

Fig. 4. Response of interest rate to forward guidance under inflation and price-level targeting. Note: The graph shows the response of the interest rate to forward guidance. The solid line represents the results under inflation targeting. The dashed line indicates the results under price-level targeting.

Overall, the results show that the beneficial effects of forward guidance increase if a central bank pursues pricelevel targeting instead of inflation targeting monetary policy. During a recession, the values of output and inflation are higher under forward guidance with price-level targeting than forward guidance with inflation targeting. Central bank forward guidance is also better able to influence agents' expectations under price-level targeting than inflation targeting. Private sector expectations under the former monetary policy regime react more favorably to forward guidance than under the latter policy. This outcome leads to higher levels of output and inflation under forward guidance with a central bank that targets the price level than the inflation rate.

\section{Investigating the differences}

The previous section showed that forward guidance is more effective under a central bank that targets the price level than the inflation rate. The current portion of this paper seeks to understand this performance gap in depth by asking the following question: is there a way to narrow this disparity? To attempt to answer this question, the rest of this section examines two notions-aggressive monetary policy and interest rate inertiathat can affect the performance of forward guidance under the two monetary policy rules.

\subsection{Aggressive monetary policy}

The first potential solution to the question of whether or not the disparity between price-level and inflation targeting with forward guidance can be alleviated regards an aggressive central bank policy. Specifically, what would the results of Section 3.2 look like if an inflation targeting regime placed a greater emphasis on deviations of the inflation rate from its target? What if a price-level targeting central bank also responded more aggressively to deviations of the price level from its target? This scenario is described next and is motivated by Billi (2008). 
The forward guidance exercise from Section 3.2 is repeated under different assumptions about the responsiveness of the central bank to deviations of inflation from its target and price level from its target. Specifically, the value of $\chi_{\pi}$ is changed from its original value of 1.4 to 2.5 . To allow a central bank under pricelevel targeting to also respond more to the price level, the value of $\chi_{p}$ increases from 0.25 to 1 . The new "aggressive" numbers are taken from Billi (2008).

Fig. 5 and Table 2 show the results of this exercise. Each line in Fig. 5 shows the difference in the values of the macroeconomic variables between forward guidance with inflation targeting and forward guidance with pricelevel targeting. For example, a negative number indicates the value of the macroeconomic variable is higher under the latter than the former monetary policy regime. The solid line represents the baseline case from Section 3.2 (i.e. $\chi_{\pi}=1.4$ and $\chi_{p}=0.25$ ). The dashed line indicates an aggressive inflation targeting central bank (i.e. $\chi_{\pi}=2.5$ ). The dotted line means an aggressive price-level targeting regime (i.e. $\chi_{p}=1$ ). The second and third panels of Table 2 also display the loss function's value under the two aggressive parameter schemes.
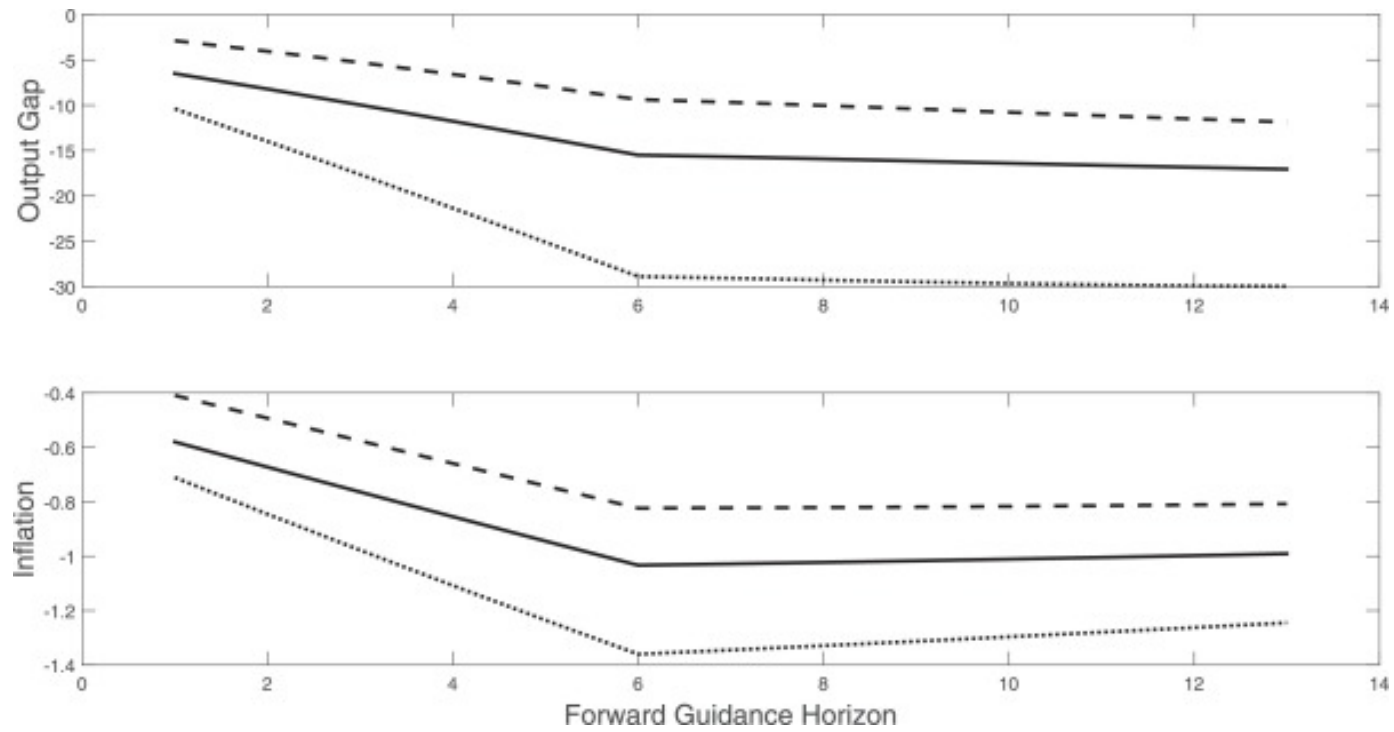

Fig. 5. Forward guidance under inflation and price-level targeting with aggressive monetary policy. Note: The graphs show the difference in the macroeconomic variables between forward guidance with inflation targeting and forward guidance with price-level targeting with or without aggressive monetary policies. A positive value indicates the value under inflation targeting is higher than under price-level targeting. A negative value indicates the variable's value under price-level targeting is higher than under inflation targeting. The solid line represents the benchmark case: $\chi_{\pi}=1.4$ and $\chi_{p}=0.25$. The dashed line indicates an aggressive inflation targeting central bank: $\chi_{\pi}=2.5$. The dotted line means an aggressive price-level targeting regime: $\chi_{p}=1$.

The results show that a more aggressive inflation targeting policy narrows the performance gap, but forward guidance still performs better with a price-level targeting regime. Fig. 5 displays that the aggressive inflation targeting policy case (i.e. the dashed line) is above the benchmark (i.e. the solid line), but still negative throughout the forward guidance horizon. Central banks that respond more to deviations of inflation from its trend close the gap between the two monetary policy regimes as indicated by the dashed line being above the solid line. However, the negative values of the dashed line still confirm the results of Section 3.2 that forward guidance performs better under price-level than inflation targeting. The second panel of Table 2 also shows that forward guidance under price-level targeting is superior to forward guidance under inflation targeting, but the disparity does decrease. The values of the loss function are 153.17 and 117.90 under forward guidance with inflation targeting and forward guidance with price-level targeting, respectively. The difference between the two previously stated values is smaller than the benchmark case of Section 3.2, but still indicates preference for forward guidance with price-level targeting than forward guidance with inflation targeting. 
Fig. 5 also displays that the difference in the performance of forward guidance between the two monetary policy regimes depends on the aggressiveness of a price-level targeting central bank. If $\chi_{p}$ increases, the superior performance of forward guidance with price-level targeting relative to forward guidance with inflation targeting grows. This result is seen in Fig. 5 as the dotted line is below the solid line. The difference in the values of the loss function in the third panel of Table 2 are also larger than under the benchmark case.

\subsection{Interest rate inertia}

A distinguishing feature of a price-level targeting monetary policy rule is its inherent history dependence as explained in Section 2.1.2. This characteristic is a reason why forward guidance produced more favorable responses of the macroeconomic variables under price-level than inflation targeting. In addition, the model in Section 2 added an amount of history dependence common to both monetary policy regimes by allowing interest rate inertia in Eqs. (6) and (12). However, a natural question may arise regarding the inclusion of $i_{t-1}$ and the performance of forward guidance under both central bank regimes. Specifically, does the performance of forward guidance with inflation targeting relative to forward guidance with price-level targeting deteriorate when interest rate inertia is not introduced into the model? To put it another way does the disparity between the two policy regimes under forward guidance decrease by allowing history dependence via $i_{t-1}$ ?

This section performs the exercise from Section 3.2 under the baseline case of interest rate inertia and no interest rate inertia. Specifically, Eqs. (6) and (12) are assumed with $\rho=0.75$ and $\rho=0$. The results are displayed in Fig. 6 and in the fourth panel of Table 2. In Fig. 6, each panel depicts the difference between the macroeconomic variable's value under forward guidance with inflation targeting and forward guidance with price-level targeting. The solid line represents the baseline case of $\rho=0.75$ and the dashed line indicates $\rho=0$. The loss function values without interest rate inertia are also displayed in the fourth panel of Table 2.
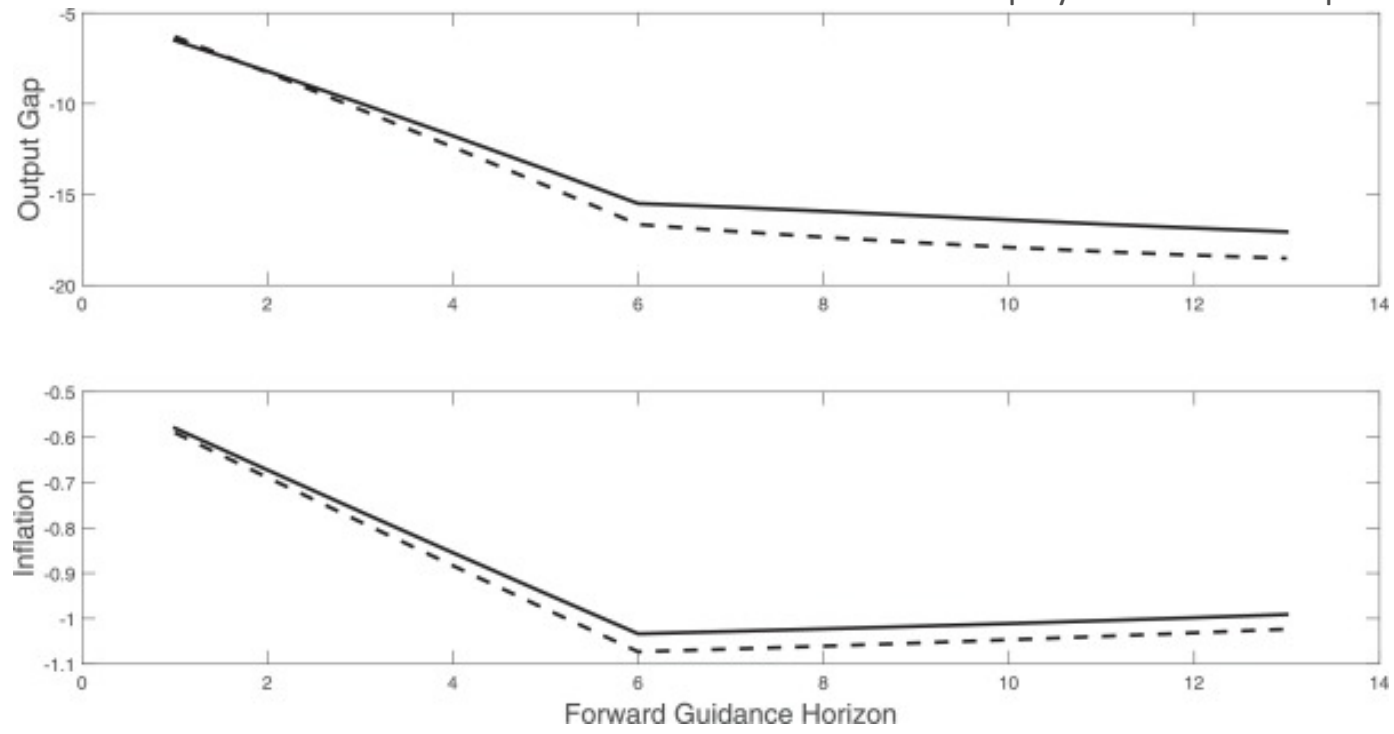

Fig. 6. Forward guidance under inflation and price-level targeting and the effect of interest rate inertia. Note: The graphs show the difference in the macroeconomic variables between forward guidance with inflation targeting and forward guidance with price-level targeting under different values of $\rho$. A positive value indicates the value under inflation targeting is higher than under price-level targeting. A negative value indicates the variable's value under price-level targeting is higher than under inflation targeting. The solid line represents the benchmark case: $\rho=0.75$. The dashed line indicates no interest rate inertia: $\rho=0$.

Overall, the results show that the introduction of interest rate inertia narrows the performance of forward guidance between the two monetary policy regimes, but with price-level targeting still preferred. When $\rho=0$, Fig. 6 reveals that output and inflation are still higher under price-level than inflation targeting. This outcome supports the main results of Section 3.2. However, these differences decrease overall when interest rate inertia is included. The second panel of Fig. 6 shows that the line without interest rate inertia (i.e. the dashed line) is below the baseline case (i.e. solid line) throughout the forward guidance horizon. ${ }^{22} \mathrm{~A}$ noticeable feature of the 
first panel is that the dashed is above the solid line (only) in the first period. However, the solid line is above the dashed line throughout the vast majority of the forward guidance horizon indicating that the differences between forward guidance with price-level targeting and forward guidance with inflation targeting decrease with the introduction of interest rate inertia. In addition, the fourth panel of Table 2 shows that the difference in the values of the loss function between forward guidance with inflation targeting and forward guidance with price-level targeting is smaller when $\rho=0.75$ than $\rho=0$. While forward guidance with price-level targeting is still preferred, the previous result indicates that the performance gap shrinks when interest rate inertia is included.

The reason for the improved performance of forward guidance with inflation targeting regards the increase in history dependence. When interest rate inertia does not exist, history dependence is found only in the pricelevel targeting rule as it responds to previous inflationary shocks. When $i_{t-1}$ exists in both monetary policy rules, inflation targeting now assumes a degree of history dependence making its characteristics and performance closer to the price-level targeting rule. In addition, this history dependence is a desirable feature for monetary policy. Giannoni (2014) explains that an optimal price-level targeting rule achieves more desirable fluctuations in the macroeconomic variables than under a Taylor rule with inflation targeting.

Overall, the results of the previous two subsections suggest additional affirmation for forward guidance with price-level targeting. A monetary authority that responds aggressively to deviations of the inflation rate from its target can improve the performance of forward guidance. However, a central bank that responds to deviations of the price level from its target is still preferable when implementing forward guidance. In addition, introducing a lagged interest rate into both models helps to improve the performance of forward guidance. However, this unconventional monetary policy still achieves better results under price-level targeting than inflation targeting.

\section{Robustness}

\subsection{Influence of price stickiness}

The results in Section 3.2 showed that beneficial effects of forward guidance increase if a central bank pursues price-level targeting instead of inflation targeting monetary policy. This result was assumed under $\alpha=$ 0.95 , which is a high degree of price stickiness in the economy. A natural question that arises is how does the effectiveness of forward guidance under price-level targeting change if the price level is more flexible. Since this monetary policy regime is inherently concerned with the price level, will the results of Section 3.2 change if price stickiness is lowered? This section investigates this question by examining the robustness of the model's results to a lower price stickiness value.

Fig. 7 and the fifth panel of Table 2 display the results under a lower value of the price stickiness parameter. To capture a lower degree of price stickiness, the dashed line in Fig. 7represents the model's results under $\alpha=0.1$. The baseline case of $\alpha=0.95$ is also included and depicted by the solid line. As is similar to the previously described exercises, each panel represents the difference between the macroeconomic variable's value under forward guidance with inflation targeting and forward guidance with price-level targeting. Furthermore, the fifth panel in Table 2 shows the values of the loss function under $\alpha=0.1$. 

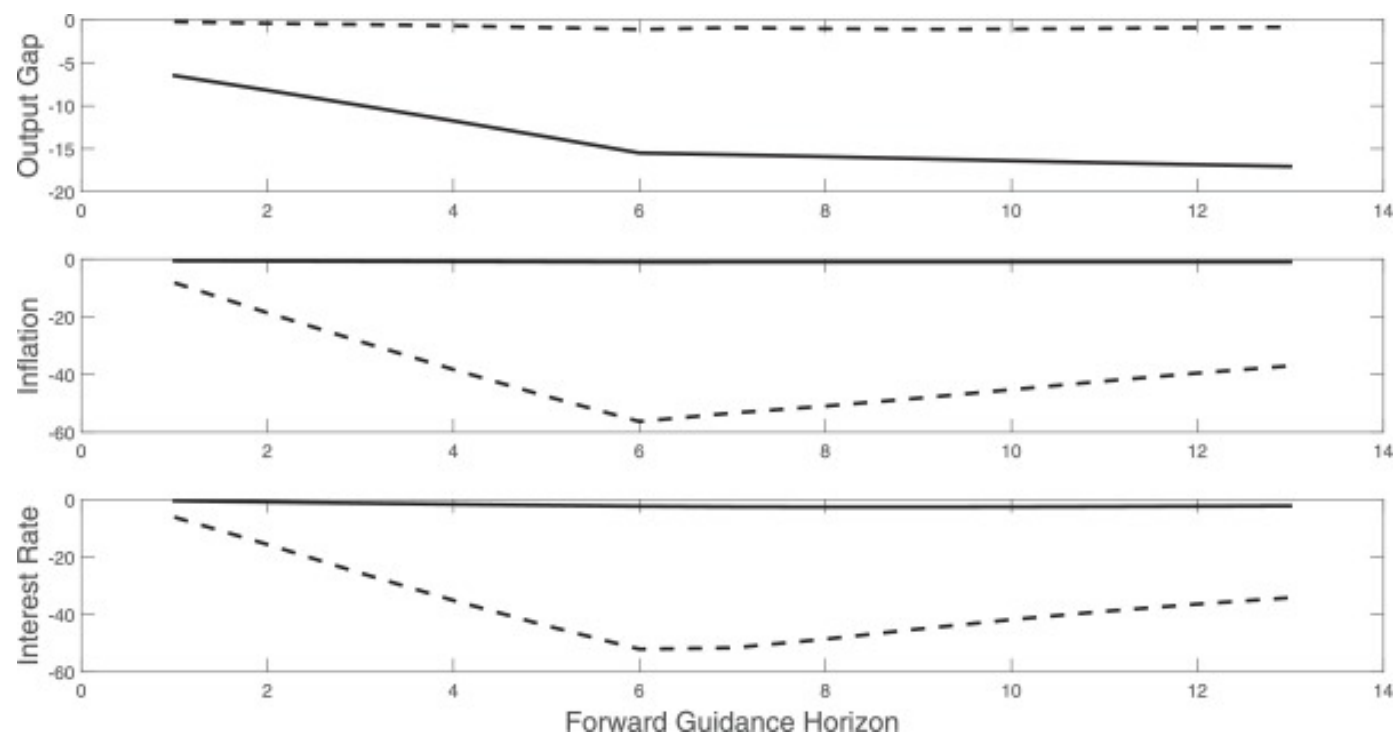

Fig. 7. Forward guidance under inflation and price-level targeting and the effect of flexible prices. Note: The graphs show the difference in the macroeconomic variables between forward guidance with inflation targeting and forward guidance with price-level targeting under different values of $\alpha$. A positive value indicates the value under inflation targeting is higher than under price-level targeting. A negative value indicates the variable's value under price-level targeting is higher than under inflation targeting. The solid line represents the benchmark case: $\alpha=0.95$. The dashed line indicates flexible prices: $\alpha=0.1$.

The results confirm that forward guidance with price-level targeting is preferred to forward guidance with inflation targeting and that flexible prices can magnify these results. The fifth panel of Table 2 shows that the value of the loss function under forward guidance with price-level targeting is still lower than under forward guidance with inflation targeting. Fig. 7displays that forward guidance produces values of output and inflation that are higher under price-level than inflation targeting across different values of $\alpha$. The output and inflation lines contain negative values throughout the entire forward guidance horizon. These results agree with the main outcomes of Section 3.2. In addition, the reduction in value of $\alpha$ changes the effectiveness of forward guidance with price-level targeting. By assuming more flexible prices in the economy, the difference between forward guidance with price-level targeting and forward guidance with inflation targeting is more favorable under $\alpha=$ 0.1 than $\alpha=0.95$. The dashed line is below the solid line in the second panel of Fig. 7 indicating a higher level of inflation under forward guidance with price-level targeting. As price stickiness decreases, the central bank can influence the price level more, and thus, forward guidance with price-level targeting is more effective than forward guidance with inflation targeting. A notable feature is that the dashed line is higher than the solid line for output. ${ }^{23}$ The reason is as follows. Because the inflation rate is higher under forward guidance with pricelevel targeting under $\alpha=0.1$ than $\alpha=0.95$, the interest rate is also higher under this monetary policy as seen in the bottom panel of Fig. 7. The higher interest rate reduces the effects on output. Therefore, the differences between output's value under forward guidance with price-level targeting and forward guidance with inflation targeting are not as large when $\alpha=0.1$ rather than $\alpha=0.95$.

\subsection{Alternative forward guidance horizons}

This section examines the importance of forward guidance effectiveness when the forward guidance horizon is changed. Specifically, does the superior performance of forward guidance under price-level targeting relative to inflation targeting depend on the length of the forward guidance horizon? To answer this question, the exercise from Section 3.2 is repeated under different values of $L$. To capture a long forward guidance horizon, the results are examined under $L=18$. This alternative is represented by the dotted line in Fig. 8 and the seventh panel in Table $2 .{ }^{24}$ To capture a short forward guidance horizon, the results are studied under $L=6$ as indicated by 
the solid line in Fig. 8 and the sixth panel in Table 2. The benchmark outcomes under $L=12$ are also represented by the dashed line in Fig. 8 .
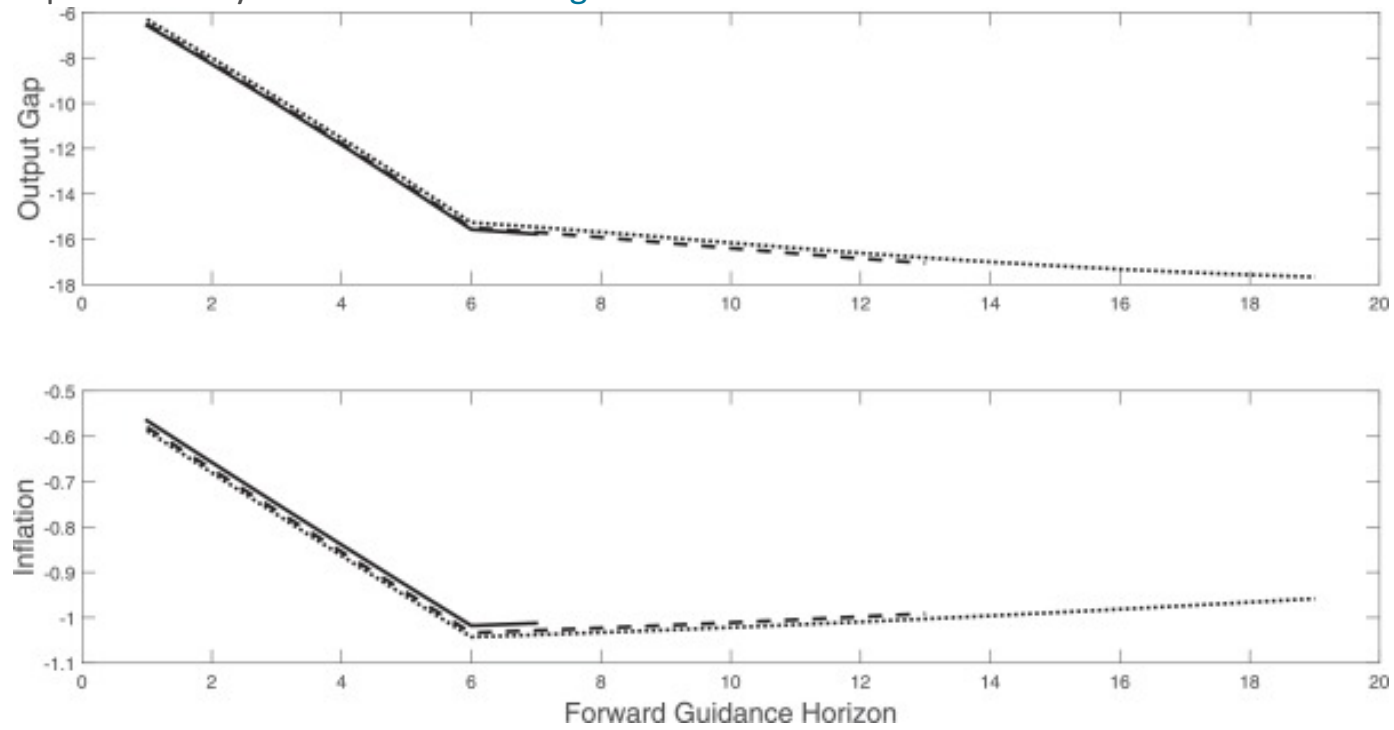

Fig. 8. The effects of forward guidance under inflation and price-level targeting and across different horizons. Note: The graphs show the difference in the macroeconomic variables between forward guidance with inflation targeting and forward guidance with price-level targeting across different forward guidance horizons. A positive value indicates the value under inflation targeting is higher than under price-level targeting. A negative value indicates the variable's value under price-level targeting is higher than under inflation targeting. The solid line represents a short forward guidance horizon: $L=6$. The dotted line indicates a long forward guidance horizon: $L=18$. The dashed line denotes the benchmark case: $L=12$.

Fig. 8 and Table 2 show that forward guidance with price-level targeting is still preferable to forward guidance with inflation targeting regardless of the length of the central bank's commitments. The values of output and inflation are higher under forward guidance with price-level targeting than inflation targeting across the different forward guidance horizons. This result is evidenced by each line in Fig. 8 being negative indicating that forward guidance with price-level targeting is more effective than forward guidance with inflation targeting. In addition, the three lines follow essentially the same path until its respective forward guidance horizon is complete. Thus, the length of the superior performance of forward guidance with price level targeting relative to inflation targeting is either increased or decreased depending on if the forward guidance horizon is extended or reduced. Furthermore, the values of the loss function confirm that forward guidance with price-level targeting is preferred regardless of the length of the forward guidance horizon. The bottom two panels in Table 2 show that the loss function is larger under forward guidance with inflation targeting than forward guidance with price-level targeting across shorter and longer horizons.

Overall, the results of the previous robustness subsections indicate preference for forward guidance with pricelevel targeting than forward guidance with inflation targeting. Forward guidance produces higher values of output and inflation under price-level than inflation targeting across low and high levels of the price stickiness parameter $\alpha$. Forward guidance also produces more favorable results under the former monetary policy scheme regardless of the length of the central bank's forward guidance horizon.

\section{Extension: optimal monetary policy}

The results of Section 3.2 studied the effectiveness of forward guidance across two simple monetary policy rules: inflation and price-level targeting. However, it would be useful to compare the performance of forward guidance under those two policy regimes to optimal monetary policy. Therefore, this section examines the results of the optimal monetary policy scenario. Following Galí (2008), the central bank is assumed to minimize: 
(16)

$\min \frac{1}{2} E_{0} \sum_{t=0}^{\infty} \beta^{t}\left(\pi_{t}^{2}+\alpha_{x} x_{t}^{2}\right)$

s.t. $\pi_{t}=\beta E_{t} \pi_{t+1}+\kappa x_{t}+\mu_{t}$

The exercise from Section 3.2 is performed under optimal monetary policy and compared to the baseline cases. ${ }^{25}$ For simplicity, this section assumes no recessionary shocks. ${ }^{26}$

The results in Fig. 9 show that the effect of forward guidance under both inflation and price-level targeting policies results in larger changes of output and inflation relative to the optimal monetary policy plan. The dashed line represents the difference between forward guidance with inflation targeting and optimal monetary policy. The dotted line denotes the difference between forward guidance with price-level targeting and optimal monetary policy. The solid line indicates the difference between forward guidance with inflation targeting and forward guidance with price-level targeting. For instance, the dashed line in the top panel of Fig. 9denotes the value of the output gap under forward guidance with inflation targeting minus the value of the output gap under optimal monetary policy. Across the forward guidance horizon, the dashed and dotted contain positive values indicating that forward guidance under both inflation and price-level targeting policies produce higher amounts of output and inflation than the optimal plan. The reason is that forward guidance is a component of both pricelevel and inflation target policies, while it is absent from optimal monetary policy. Forward guidance on the inflation target creates increased positive changes to the expectations of agents, and thus, increases current output and inflation.
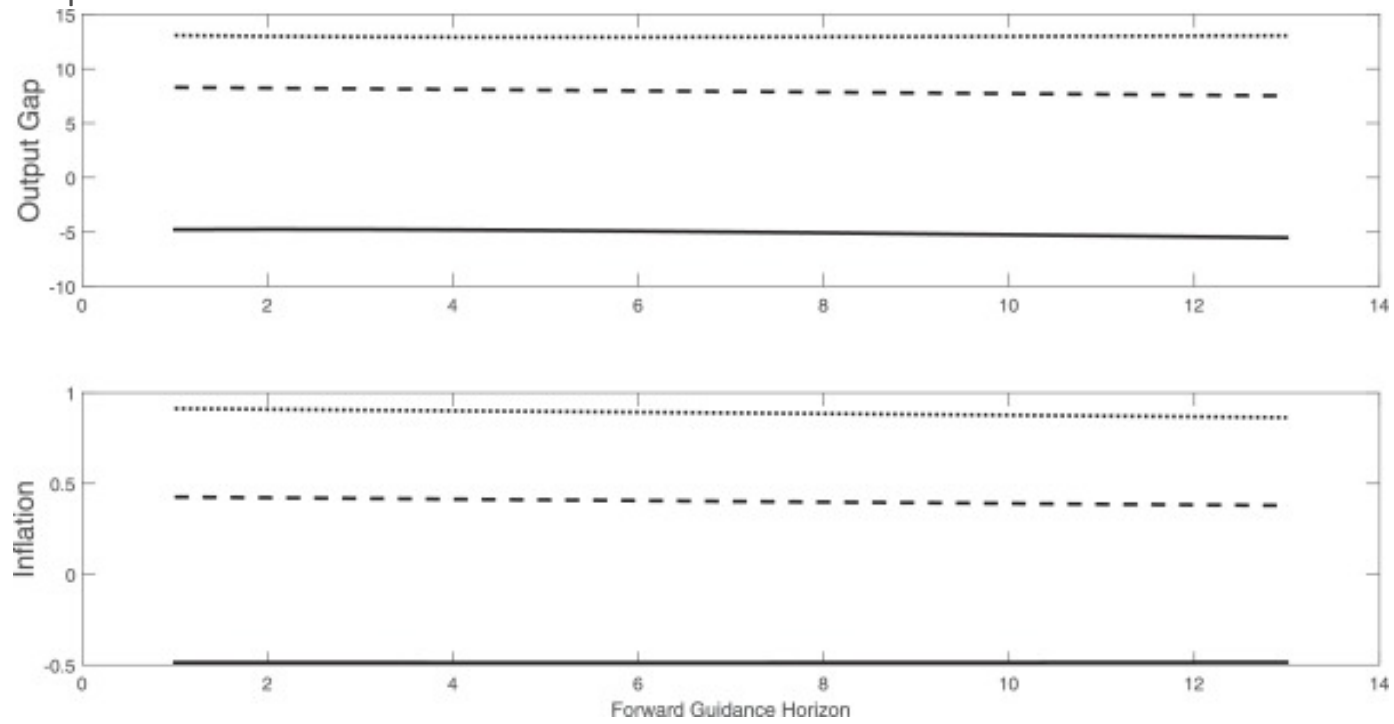

Fig. 9. Forward guidance under inflation and price-level targeting vs. optimal monetary policy. Note: The graphs show the difference in the macroeconomic variables between forward guidance with inflation targeting and optimal monetary policy (dashed line), forward guidance with price-level targeting and optimal monetary policy (dotted line), and forward guidance with inflation targeting and forward guidance with price-level targeting (solid line). For instance, the dashed line in the top panel of Fig. 9 denotes the value of the output gap under forward guidance with inflation targeting minus the value of the output gap under optimal monetary policy.

The higher levels of output and inflation also imply greater changes in the loss function with forward guidance under inflation and price-level targeting relative to optimal monetary policy. For this section, the welfarerelevant loss function is computed as in Galí (2008). The values of the welfare-relevant loss function for forward guidance with inflation targeting, forward guidance with price-level targeting, and optimal monetary policy are 43.77, 104.96, and 13.13, respectively. ${ }^{27}$ The reason for the discrepancy between forward guidance under the 
two baseline policy specifications and optimal monetary policy is that output and inflation change more under forward guidance with inflation and price-level targeting policies as seen in Fig. 9. The larger movement in these variables causes higher variation and thus relatively larger values of the welfare-loss function. Moreover, the scope of this paper focused on how the effectiveness of forward guidance varies across inflation and price-level targeting regimes. The results in this section still confirm the main results of the paper: forward guidance with price-level targeting outperforms forward guidance with inflation targeting as seen in Fig. 9.

\section{Conclusion}

Forward guidance has emerged as a pertinent tool for central bank authorities since the 2007-2009 Great Recession. However, U.S. inflation has continually missed the Federal Reserve's target of $2 \%$ over the period May 2012 to January 2017. In addition, since the global financial crisis, price-level targeting has gained notable attention due to its predictions of above-average inflation in response to deflationary episodes. Thus, it is of interest to investigate whether forward guidance's effect on the economy can be increased under a central bank targeting the price level instead of the inflation rate.

This paper investigates the effectiveness of central bank forward guidance across two policy regimes: inflation and price-level targeting. The results show that the beneficial effects of forward guidance increase if a central bank pursues price-level targeting instead of inflation targeting monetary policy. When the central bank communicates guidance on the future course of its inflation target, output and inflation produce more favorable responses to forward guidance under price-level targeting than inflation targeting during an economic crisis. The reasons are twofold. The inherent history dependence feature of the former monetary policy implies a period of above average inflation. Agents' expectations of output and inflation also respond more favorably to forward guidance with price-level targeting than inflation targeting. This previous statement provides a key contribution of this paper to previous research. Prior literature has shown that price-level targeting can greatly influence the expectations of agents relative to inflation targeting (see Billi, 2008). Since forward guidance operates through the expectations channel, the current paper shows that the effectiveness of forward guidance is increased by a price-level targeting policy relative to an inflation targeting strategy. In addition, the performance gap between the two monetary policies narrows if a central bank aggressively responds to the inflation rate and includes interest rate inertia in its monetary policy role. However, output and inflation still respond more favorably to forward guidance under price-level than inflation targeting. The results are also robust to flexible or rigid prices and shorter or longer forward guidance horizons. Overall, the type of targeting policy by a central bank is important when understanding the effectiveness of central bank forward guidance.

\section{References}

Amano, Engle-Warnick, Shukayev, 2011. R. Amano, J. Engle-Warnick, M. Shukayev. Price-level targeting and inflation expectations: experimental evidence. Technical Report, Bank of Canada working paper (2011)

Ambler, 2009. S. Amble. rPrice-level targeting and stabilization policy: a review. Bank Canada Rev. (2009), pp. 19-29

Ball, Mankiw, Reis, 2005. L. Ball, N.G. Mankiw, R. Reis. Monetary policy for inattentive economies. J. Monet. Econ., 52 (4) (2005), pp. 703-725

Billi, Billi, R. M., 2008. Price-level targeting and risk management in a low-inflation economy. Federal Reserve Bank of Kansas City Working Paper (08-09).

Billi. Billi, R. M., 2015a. A note on nominal GDP targeting and the zero lower bound. Sveriges Riksbank Working Paper (270).

Billi. Billi, R. M., 2015b. Price level targeting and risk management. Sveriges Riksbank Working Paper Series (302). Bundick, 2015. B. Bundick. Real Fluctuations at the Zero Lower Bound. Technical Report, mimeo (2015) Calvo, 1983. G. Calvo. Staggered prices in a utility-maximizing framework. J. Monet. Econ., 12 (3) (1983), pp. 383-398 
Carlstrom, Fuerst, Paustian. Carlstrom, C., Fuerst, T., Paustian, M., 2012. Inflation and output in new Keynesian models with a transient interest rate peg.(Working Paper No. 459). Retrieved

from: http://www.bankofengland.co.uk/research/documents/workingpapers/2012/wp459.pdf.

Cole, 2015. S. Cole. Learning and the effectiveness of central bank forward guidance. Technical

Report, Working paper, UC-Irvine (2015)

Cole, 2016. S. Cole. The limits of Central Bank forward guidance under learning. Technical Report, Marquette

University, Center for Global and Economic Studies and Department of Economics (2016)

Côté. Côté, A., 2007. Price-level targeting.Discussion Paper/Document d'analyse 2007-8.

Cover, Pecorino, 2005. J.P. Cover, P. Pecorino. Price and output stability under price-level targeting. South. Econ. J. (2005), pp. 152-166

De Graeve, Ilbas, Wouters. De Graeve, F., Ilbas, P., Wouters, R., 2014. Forward guidance and long term interest rates: inspecting the mechanism. Sveriges Riksbank Working Paper Series (292).

Del Negro, Giannoni, Patterson. Del Negro, M., Giannoni, M., Patterson, C., 2012. The forward guidance puzzle. FRB of New York Staff Report (574).

Del Negro, Giannoni, Schorfheide, 2014. M. Del Negro, M.P. Giannoni, F. Schorfheide. Inflation in the great recession and new Keynesian models. Technical Report, National Bureau of Economic Research (2014)

Dowd, 2007. K. Dowd. Too good to be true? The (in) credibility of the UK inflation fan charts. J. Macroecon., 29 (1) (2007), pp. 91-102

Eggertsson, Woodford, 2003. G.B. Eggertsson, M. Woodford. The zero bound on interest rates and optimal monetary policy. Brookings Pap. Econ. Act. (1) (2003), pp. 139-211

Evans, 2012. C.L. Evans. Monetary policy in a low-inflation environment: developing a state-contingent pricelevel target. J. Money Credit Bank., 44 (s1) (2012), pp. 147-155

Federal Reserve. Federal Reserve, 2012. Federal reserve issues FOMC statement of longer-run goals and policy strategy. Retrieved from https://www.federalreserve.gov/newsevents/pressreleases/monetary20120125c.htm.

Fuhrer, 2000. J.C. Fuhrer. Habit formation in consumption and its implications for monetary-policy models. Am. Econ. Rev. (2000), pp. 367-390

Galí, 2008. J. Galí. Monetary policy, inflation, and the business cycle: an introduction to the new keynesian framework. Princeton University Press (2008)

Gaspar, Smets, Vestin. Gaspar, V., Smets, F., Vestin, D., 2007. Is time ripe for price level path stability?European Central Bank Working Paper (818).

Giannoni, 2014. M.P. Giannoni. Optimal interest-rate rules and inflation stabilization versus price-level stabilization. J. Econ. Dyn. Control, 41 (2014), pp. 110-129

Haldane, Salmon, 1995. A.G. Haldane, C.K. Salmon. Three issues on inflation targets. Targeting Inflation (1995), pp. 170-201

Hall, Mankiw, 1994. R.E. Hall, N.G. Mankiw. Nominal income targeting. Monetary policy, The University of Chicago Press (1994), pp. 71-94

Hall, et al., 1984. R.E. Hall, et al.. Monetary strategy with an elastic price standard. Proceedings-Economic Policy Symposium-Jackson Hole, Federal Reserve Bank of Kansas City (1984), pp. 137-167

Hills, Nakata. Hills, T., Nakata, T., 2014. Fiscal multipliers at the zero lower bound: the role of policy inertia. FEDS Working Paper (2014-107).

Honkapohja, Mitra, 2015a. S. Honkapohja, K. Mitra. Comparing inflation and price-level targeting: the role of forward guidance and transparency. The Manchester School, 83 (S2) (2015), pp. 27-59

Honkapohja, Mitra, 2015b. S. Honkapohja, K. Mitra. Targeting prices or nominal GDP: forward guidance and expectation dynamics. Technical Report, mimeo (2015)

Kuester, Müller, Stölting. Kuester, K., Müller, G. J., Stölting, S., 2007. Is the new Keynesian Phillips curve flat?European Central Bank Working Paper (809).

Laséen, Svensson, 2011. S. Laséen, L.E. Svensson. Anticipated alternative policy rate paths in policy simulations. Int. J. Central Bank (2011) 
Lebow, Roberts, Stockton, et al., 1992. D.E. Lebow, J.M. Roberts, D.J. Stockton, et al. Economic performance under price stability. Technical Report, Board of Governors of the Federal Reserve System (US) (1992)

Levin, López-Salido, Nelson, Yun, 2010. A. Levin, D. López-Salido, E. Nelson, T. Yun. Limitations on the effectiveness of forward guidance at the zero lower bound. Int. J. Central Bank. (2010)

McKay, Nakamura, Steinsson, 2015. A. McKay, E. Nakamura, J. Steinsson. The power of forward guidance revisited. Technical Report, National Bureau of Economic Research (2015)

Milani, 2007. F. Milani. Expectations, learning and macroeconomic persistence. J. Monet. Econ., 54 (7) (2007), pp. 2065-2082

Milani, 2009. F. Milani. Learning and the Evolution of the Fed's Inflation Target. Technical Report, mimeo, University of California, Irvine (2009)

Milani, Treadwell, 2012. F. Milani, J. Treadwell. The effects of monetary policy "news" and "surprises". J. Money Credit Bank., 44 (8) (2012), pp. 1667-1692

Orphanides, Williams, 2006. A. Orphanides, J.C. Williams. Monetary policy with imperfect knowledge. J. Eur. Econ. Assoc., 4 (2-3) (2006), pp. 366-375

Preston, 2005. B. Preston. Learning about monetary policy rules when long-horizon expectations matter. Int. J. Central Bank., 1 (2) (2005), pp. 81-126

Schmitt-Grohé, Uribe, 2012. S. Schmitt-Grohé, M. Uribe. What's news in business cycles. Econometrica, 80 (6) (2012), pp. 2733-2764

Shukayev, Ueberfeldt. Shukayev, M., Ueberfeldt, A., 2010. Price level targeting: what is the right price?Working Paper/Document de travail.

Svensson, 1999. L. Svensson. Price-level targeting versus inflation targeting: a free lunch? J. Money Credit Bank. (Ohio State University Press), 31 (3) (1999)

Swanson, Williams, 2014. E.T. Swanson, J.C. Williams. Measuring the effect of the zero lower bound on medium-and longer-term interest rates. Am. Econ. Rev., 104 (10) (2014), pp. 3154-3185

Taylor, 1993. J.B. TaylorDiscretion versus policy rules in practice. Carnegie-Rochester conference series on public policy, 39, Elsevier (1993), pp. 195-214

Vestin, 2006. D. Vestin. Price-level versus inflation targeting. J. Monet. Econ., 53 (7) (2006), pp. 1361-1376

Williams, 2010. J.C. Williams. Monetary policy in a low inflation economy with learning. Econ. Rev.-Federal Reserve Bank of San Francisco (2010), p. 1

Wolman, 2005. A.L. Wolman. Real implications of the zero bound on nominal interest rates. J Money Credit Bank., 37 (2) (2005), pp. 273-296

Woodford, 2003. M. Woodford. Interest and prices: foundations of a theory of monetary policy. Princeton University Press (2003)

${ }^{1}$ Inflation is defined as the twelve-month growth rate of the Personal Consumption Expenditures Price Index. This index can by found on the FRED database of the Federal Reserve Bank of St. Louis. The acronym is PCEPI.

${ }^{2}$ For instance, Evans (2012) describes the positive benefits of price-level targeting when Federal Reserve policy has failed to achieve its dual mandate.

${ }^{3} \mathrm{Hall}$ et al. (1984) and Hall and Mankiw (1994) also argue that price-level targeting helps with personal planning. For instance, they explain that a more stable and predictable price level caused by price-level targeting benefits the purchasing power of private pensions.

${ }^{4}$ In the model presented in this paper, I also assume interest rate inertia to both inflation and price-level targeting regimes. This feature adds a degree of common history dependence to both policies. However, price-level targeting still has the inherent history dependence as discussed in this paragraph.

${ }^{5}$ This is akin to the FOMC stating its long-run objective for inflation of $2 \%$.

${ }^{6}$ For additional discussion of the positive benefits of price-level targeting, see Côté (2007) and Ambler (2009).

${ }^{7}$ Honkapohja and Mitra (2015a) also perform a similar analysis without nominal GDP targeting. 
${ }^{8}$ The two monetary policy regimes considered in this paper are inflation targeting and price-level targeting. The former policy is standard practice among central banks, while the latter has gained recent attention because of its beneficial predictions on the inflation rate (see Evans, 2012).

${ }^{9}$ Forward guidance on a policy variable other than the interest rate variable has been previously modeled in the literature. For example, Honkapohja and Mitra (2015a) and Honkapohja and Mitra (2015b) incorporate forward guidance on the target path of the price level under price-level targeting regime. However, forward guidance is not included in the inflation targeting monetary policy.

${ }^{10}$ Milani and Treadwell (2012) model the time-varying inflation target in a similar fashion to (8), but their focus is on policy news and not forward guidance.

${ }^{11}$ Schmitt-Grohé and Uribe (2012) utilize the anticipated shocks from a news perspective. Cole (2016); 2015), and Del Negro et al. (2012) model the anticipated shocks as forward guidance on the interest rate.

${ }^{12}$ Eqs. (9)-(11) are also added to the system as forward guidance is defined in the same way as in Section 2.1.1.

${ }^{13}$ Bundick (2015) and Hills and Nakata (2014) show the significance of history dependence in monetary policy when the economy is at the ZLB.

${ }^{14}$ Cole (2016); 2015), and Del Negro et al. (2012) conduct a similar exercise with forward guidance on the interest rate.

${ }^{15}$ This forward guidance should not be interpreted as temporarily raising the inflation target in response to recessionary shocks. Rather, it is clarification and direction about the target rate of inflation in the short term (i.e. low inflation period) and long term. Indeed, Section 5.2 examines the results when $L$ is increased to include longer horizons.

${ }^{16}$ The six period length of the recession corresponds to the duration of the 2007-2009 global financial crisis defined by the National Bureau of Economic Research.

${ }^{17}$ Billi (2015a) has examined the effects of three different monetary policy regimes-a simple monetary policy rule, price-level targeting, and nominal GDP targeting-under an adverse demand shock, but without forward guidance.

${ }^{18}$ Williams (2010) examines price-level targeting under the adaptive learning approach. Honkapohja and Mitra (2015b) and Orphanides and Williams (2006) also use a similar loss function. In addition, in the context of the exercise of this section, the time-varying inflation target in Eq. (15) will be fixed across the forward guidance horizon. As explained in the third paragraph of this section, the unanticipated inflation and forward guidance shocks are chosen such that $\pi \mathrm{t}^{*}=\pi^{*}$ across the entire forward guidance horizon.

${ }^{19} \mathrm{~A}$ notable finding in the forward guidance literature regards the "forward guidance puzzle" of Del Negro et al. (2012). They find that standard macroeconomic models predict an unusually large reaction of macroeconomic variables to forward guidance. Subsequent research has proposed reasons for this finding (e.g. McKay et al., 2015 and Cole, 2015). However, the focus of this paper is to show how the effects of forward guidance vary depending on the monetary policy regime. Thus, while it would be an interesting topic to consider for a future study, it would be beyond the purpose of the paper to offer a solution to the forward guidance puzzle with the model presented in this paper.

${ }^{20} \mathrm{Billi}$ (2008) examines price-level targeting but does not include forward guidance.

${ }^{21}$ These numbers are higher compared to Williams (2010) who investigated price-level targeting without forward guidance. However, the recession assumed in this current paper can add to the loss function's total.

${ }^{22}$ The results agree with Giannoni (2014) who found that price-level targeting regimes are still preferable to inflation targeting when a high level of interest rate inertia exists in the model.

${ }^{23}$ However, the dashed line is still negative indicating higher values of output under price-level targeting than inflation targeting.

${ }^{24} \mathrm{As}$ is similar to 3.2 The effects of forward guidance under inflation and price-level targeting, Fig. 8 shows the difference in forward guidance's effectiveness between inflation and price-level targeting. Thus, a negative value indicates that the value of the macroeconomic variable is larger under forward guidance with price-level targeting than forward guidance with inflation targeting.

${ }^{25}$ The value of $\alpha_{x}$ equals 0.048, which is taken from Giannoni (2014). 
${ }^{26}$ The main results do not change, that is, forward guidance with price-level targeting outperforms forward guidance with inflation targeting as Fig. 9 shows.

${ }^{27}$ The reason that the welfare-relevant loss function's value is greater under forward guidance with price-level targeting than inflation targeting is as follows. Since output and inflation are higher under the former regime and there are no recessionary shocks in this scenario, higher amounts of variation under forward guidance with price-level targeting imply a larger value of the welfare-relevant loss function relative to forward guidance with inflation targeting. Moreover, the main results of the paper still hold as forward guidance with price-level targeting outperforms forward guidance with inflation targeting as seen in Fig. 9. 